\title{
Arabic Gum Role in Ameliorating Cyclosporine- A Initiated Nephrotoxicity in Rats
}

\author{
Hosam-Eldin Hussein Osman', Doaa Galal ELSahra', Ayman El-Meghawry \\ El-Kenawy ${ }^{3}$ and Rasha R. Salem ${ }^{4}$
}

Original

${ }^{1}$ Department of Anatomy, College of Medicine, Taif University

${ }^{2}$ Modern Technology and Information University

${ }^{3}$ Department of Pathology, College of Medicine, Taif University, Department of Molecular Biology, GEBRI, University of Sadat city

${ }^{4}$ Department of Anatomy, Faculty of Medicine, Alexandria University, Egypt

\begin{abstract}
Background: Recently many researchers reported that treatment using cyclosporine A in extended period in order to avoide the rejection of allograft is connected with renal impairment progress. Arabic gum is a valuable antioxidants and anti-carcinogenic factor with a protective effect against renal intoxications.

Aim: This research aims at assessing the improving function of Arabic gum in ameliorating nephrotoxicity of cyclosporine A in adult rats by measuring urea and creatinine as renal function tests and histopathological changes plus redox status parameters. Materials and Methods: 80 mature rats males and females were classified into four groups during the period of expirment (45 days) first one act as control given saline; the second one was given $7.5 \mathrm{gm} / \mathrm{kg} /$ day of Arabic gum , while third group was given cyclosporine A( $25 \mathrm{mg} / \mathrm{kg} /$ day ) finally the fourth one was given $7.5 \mathrm{gm} / \mathrm{kg} /$ day of Arabic gum together with the $25 \mathrm{mg} /$ $\mathrm{kg} /$ day of cyclosporine A.

Results: Cyclosporine A group three rats had renal impairment beside injury, when reported by elevated values of urea and creatinine and renal pathological changes, relative to the first group(control) with high level of cyclosporine A in blood and bad parameters of redox status. Receiving of (Arabic gum) accompanied with (cyclosporine A) ameliorating renal damage by decreasing the level of urea and creatinine in the blood, renal histo pathological amelioration, moreover the improved parametersof antioxidant. The levels of catalase, glutathione, peroxidase and superoxide dismutase were statistically reduced as regard group three G3 (cyclosporine) which was significant relative to the control \& second groups G1,G2 although significantly elevated in the fourth group which given cyclosporine plus Arabic gum when compared with the third group (cyclosporine).

Conclusion: Arabic gum has likely to behave like natural agent opposing cyclosporine A -provoked nephrotoxicity.
\end{abstract}

Received: 03 August 2020, Accepted: 26 October 2020

Key Words: Arabic gum, cyclosporine A., renal impairment.

Corresponding Author: Rasha R. Salem, PhD, Department of Anatomy, Faculty of Medicine, Alexandria University, Egypt, Tel.: +20 1025712480, E-mail: rasha_elrechy_omar@yahoo.com

ISSN: $1110-0559$, Vol. 44, No.3

\section{INTRODUCTION}

In the most recent decades many researchers detected that the greatest recent tendency in the treatment of many variable diseases as end-stage of liver and kidney dysfunction and injury is the organ transplantation. Also great risk of the failure of transplanted organ is the main problem in front of researchers which treated by taking immunosuppressive drugs clinically ${ }^{[1]}$.

Cyclosporine- $\mathrm{A}$ is an immunosuppressive drug which has become most strong popular immunosuppressive of choice for renal,liver, pancreatic, and cardiac transplantation, one of its side effects of long period clinical use is nephrotoxicity which consists of a reversible, raise in serum creatinine, hyperkalemia, hypertension, metabolic acidosis, and chronic interstitial nephritis with irreversible worsening in renal function ${ }^{[2]}$.
Despite results of acute and chronic cyclosporineA -induced impairment of renal function mechanism is controversial, but accurate mechanisms concerned in these toxic manifestations of cyclosporine-A on the function of kidney are not well understood, even though they may reveal tubular toxicity, particularly in the the proximal tubule in its straight segment ${ }^{[3]}$. Also it has direct effect on inhibition of calcineurin, excessive expression of fibrous intermediaries, like the transforming growth factor $\beta 1$ (TGF- $\beta 1$ ), and vascular insufficiency, including angiotensin II, thromboxane A (TXA) nitric oxide (NO), serotonin, leukotriene and catecholamine, in addition to elevating the production of reactive oxygen species (ROS) that results in oxidative hassle and distress ${ }^{[4,5]}$.

Plants and herbs are well thought-out as a folk medicine which has been handled as a previous style by the old grandfathers in order to manage various cases, moreover 
they are recently considered as useful modulators of various agents intoxication like an original style in the current medicine ${ }^{[6,7,8]}$. In Middle Eastern countries ,Arabic gum was long taken in Arab folk medicine to decrease equally the frequency and the call for heamodialysis in those complained of chronic renal impairment and used in the traditional medicinal practices. Moreover to that latest researches revealed that Arabic gum decreased the nitrogen excretion in urine by mounting urea removal inside large intestine plus decreasing urea level in the blood of rat and human .Treatment with Arabic gum (AG) was reported to rise creatinine removal, reduce the concentration of plasma phosphate, proteinuria and the excretion of phosphate as well as sodium in urine. Also many researches have detected the effect of Arabic gum (AG) on models of experiments of kidney diseases and revealed its role in limiting their sequence ${ }^{[9]}$.

These majort effects might augment value of Arabic gum (AG) in dealing with chronic renal diseases like failure and diabetic nephropathy ${ }^{[10,11]}$.

Arabic gum $(\mathrm{AG})$ is dietary fiber which is water-soluble and resultant from the dehydrated sticky exudates from the branches and the stems of Acaia senegal (Leguminosae), has magnesium, calcium, and salts of potassium of polysaccharide Arabic gum acid ${ }^{[11]}$. Conversely, a lack of information which giving scientific background about the folkloric claims of Arabic gum (AG) on renal function following renal injury is present. Recent researches revealed that $(\mathrm{AG})$ has antioxidant, protection ofnephron and other major anti-inflammatory roles on digestive system $^{[12,13]}$

So, our aim in this research was to determine the renoprotective role of Arabic gum in ameliorating cyclosporine-A initiated nephrotoxicity in adult rats which have renal damage and injure, and focuse on its antioxidant properties.

\section{MATERIAL AND METHODS}

80 adult rats $(200-250$ g)of both sexes were brought from the animal house of Alexanderia University. The rats were under a day-night regimen of $12 \mathrm{~h} / 12 \mathrm{~h}$ and easy contact . the rats were given food, water and balanced diet ad libitum through the experiment exactly forty five days. Animals were put into four groups $(\mathrm{G})$ ( $\mathrm{n}=20$ each one); $\mathrm{G} 1$ given physiological saline as control group, $\mathrm{G} 2$ given 10 $\mathrm{gm} / \mathrm{kg} /$ day of arabic gum ${ }^{[14]}$. G3 were given $25 \mathrm{mg} / \mathrm{kg} /$ day of cyclosporine dissolved in physiological saline ${ }^{[15]}$, at the same time $\mathrm{G} 4$ given $10 \mathrm{gm} / \mathrm{kg} /$ day of Arabic gum together with the same cyclosporine dose of the third group $(25 \mathrm{mg} /$ $\mathrm{kg}$ /day of cyclosporine dissolved in physiological saline).

Cyclosporine-A and Arabic gum were applied daily utilizing gastric gavage ${ }^{[14]}$. Cyclosporine-A was present in a soft gelatin capsule $(50 \mathrm{mg})$ that was purchased from Novartis Pharma, while arabic gum was purchased from the market as spherical tears that were crushed and sieved in order to get tiny clean powder. The concentrate was 10 g/ $100 \mathrm{ml}$. then were put into warm water to dissolve them after that they were taken by the rats via mouth ${ }^{[14]}$.

\section{Blood Sample Collection}

24 hours after the experiment, the animals were anesthetized using diethyl ether and weighted then withdrawal of blood from orbital sinus was done by (EDTA capillary tubes were used). Centrifugation of the blood was done to get the serum necessary for detection of (urea \& creatinine) that were measured by the ordinary colorimetric wayes ${ }^{[16]}$. Measuring of Cyclosporine level was determined in the blood which was obtained 12 hours after the last dose of the drug ${ }^{[15]}$

\section{Histopathological examination}

Dissection of kidneys from all groups was done then weighing them carefully, they were put in $10 \%$ formal saline for fixation, dehydrated in ascending grades of alcohol, cleared in xylene, after that embedded in paraffin, the tissue sections were stained with haematoxylen and eosin, periodic acid Schiff(PAS) and Mallory stain for light microscope examination ${ }^{[17]}$.

For ultrastructure studies fixation done at $4^{\circ} \mathrm{c}$ for 1.5 hours using $2.7 \%$ glutaraldehyde solution plus $0.1 \mathrm{M}$ of phosphate buffer and then put in $(0.15 \mathrm{M}$ of phosphate buffer, $\mathrm{pH}$ 7.2), then fixed in osmic acid solution of $1 \%$ concentration in $0.15 \mathrm{M}$ phosphate buffer during an hour under $4{ }^{\circ} \mathrm{c}$. Dehydration was done by ascending grades of acetone after that embedding in epoxy resin Epon 812. After blocking, they were sectioned with an ultramicrotome type LKB at $70 \mathrm{~nm}$ thickness. Double contrasting of the sections with solutions of uranyl acetate and lead citrate occurred for examination by the use of transmission electron microscope ${ }^{[17]}$.

\section{Tissue preparation}

Homogenization of $500 \mathrm{mg}$ of renal samples was occurred in $4 \mathrm{ml}$ of the buffer solution (phosphate buffered saline with $\mathrm{PH}$ 7.4) whereas centrifugation the homogenates were done at $10.000 \mathrm{xg}$ (time: 15 minutes at $4^{\circ} \mathrm{c}$ ). The resultant was ready and utilized in detecting peroxidative stress markers like malondialdehyde ("MDA") plus antioxidant enzymes assay like catalase "CAT", peroxidase, glutathione "GSH", Nitric oxide and superoxide dismutase "SOD", ${ }^{[18]}$.

\section{Statistical analysis}

For statistical study, (SPSS of version 17) was utilized. Outcomes were reported, using of (one-way ANOVA, posthoc multiple comparisons test (TUKEY)) to detect any variation within various groupings. Mean $+\mathrm{SD}$ expressed as results variability while $P$ value that equals to 0.05 or less was reported as statistically significant.

\section{Ethical considerations}

suitable species of rats were selected during the present study. An elevated level of well-being rat is improved at 
all times. The best size of sample was intended utilizing the lowest number of adult rats to get accurate results. Procedures causing pain done by the effect of anesthesia to inhibit any painful sensation and stress. animal safety with handling standards went parallel to the appropriate international rules and policy. There was approval from the ethics committee with a resolution no of 7703

\section{RESULTS}

changes of the weight of both body and kidney in various experimental groups

A significant reduction in the weight of rats of third group relative to group1 and group 2. While, the rats' body weight of G4 had a significant rise relative to that of of G3 (Figure 1).

kidneys of rats of third group (cyclosporine) revealed significant reduce in weight relative to the control and second groups, but kidneys of rats of group 4 had a significant rise statistically relative to the second group (Figure 2).

A significant result was found statistically among groups. when $P<0.001$.

\section{Measuring of cyclosporine level}

Level of Cyclosporine-A in the serum of rats of third group was elevated with a significant difference relative to group 1 and group 2 although the cyclosporine blood level of rats of fourth group showed statistically significant difference When compared with the third group (Figure 3).

A significant result statistically was present among groups when $P<0.001$

\section{Biochemical results}

\section{I-Urea \&creatinine}

Urea and creatinine values of cyclosporine-A in group3 had a significant increase relative to $\mathrm{G} 1$ but the levels of urea and creatinine of G2 and G4 had statistically significant decrease in relation to G3 (Table 1).

\section{II- Redox status parameters}

A significant reduce in the levels of catalase, peroxidase, glutathione and superoxide dismutase in group 3 in relation to the control and second groups G1\&G2 but significantly increased levels in G4 relative to G3 Although, the levels of malondialdehyde (MDA) and nitric oxide were significantly raised in G3 when compared with G1\&G2. while it significantly reduced in G4 when compared with G3 (Table 2).

\section{Histopathological results}

\section{A- Light microscopic results}

Microscopic observation of tissues of cortical tissues in rats of $\mathrm{G} 1$ and $\mathrm{G} 2$ revealed normal appearance (Figures 4,7), periodic acid Schiff (PAS) stain in glomeruli and tubules (brush borders) was positive (Figure 10) But, specimens from rats of group 3 which were treated with cyclosporine, revealed atrophy and damage of cells plus cystic dilatation of the tubules, the epithelium of Bowman's capsule was injured with large size glomeruli (Figures 5,8) and fibrosis among the interstitium positive periodic acid Schiff reaction (weak reaction) was detected in vascular media, capillaries of glomeruli and renal tissues. (Figure 11) As regard the forth group, the cortical tissue showed restoration of histological normal appearance, the cytoplasm of cells of renal tubules was strong acidophilic and the nuclei were vesicular (Figures 6,9), there was strong positive (PAS) stain in glomeruli and tubules(brush borders) of kidney of the G4 (Figure 12) .

\section{B- transmission electron microscopic results}

G1\&G2 revealed normal ultrastructure appearance (Figure 13) But, renal cellular structures of G3 revealed nuclear shrinkage in the cells of proximal convoluted tubules, most of cytoplasmic organelles were degenerated with several vacuoles of multiple sizes, obvious swollen few mitochondria ,the basement membrane of tubules was thick and disturbed microvilli in brush border (Figure 14) On the other hand, rats of G4 showed nearly the same ultrastructure of G1 and G2 whereas mitochondria and the nucleus were almost normal with well-formed microvilli (Figure 15).

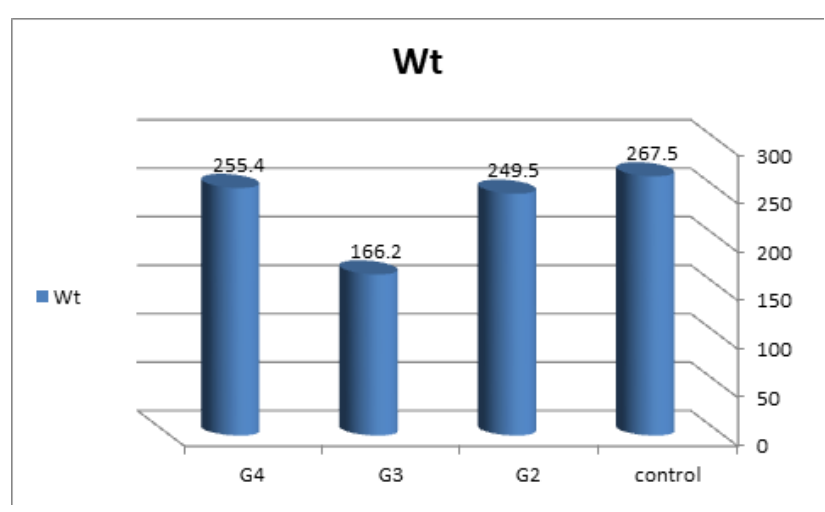

Fig. 1. Body weight among different groups

G1: (control group). - G2: Arabic gum (AG).

G3: Cyclosporine (CsA). - G4: Cyclosporine and Arabic gum (CsA+AG)

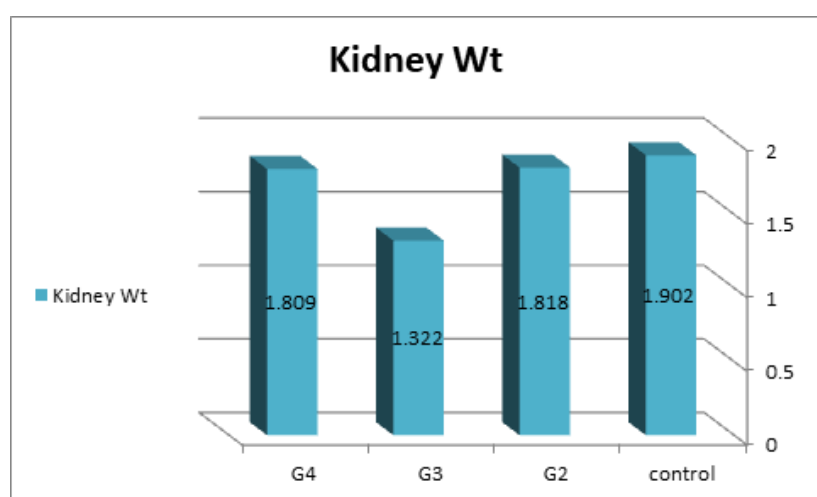

Fig 2: The rats' kidney weight among the four groups 


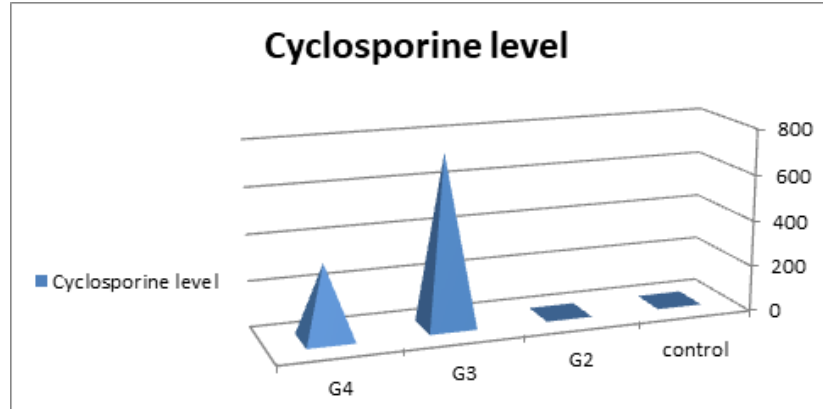

Fig. 3: Rats' cyclosporine blood level among the four groups

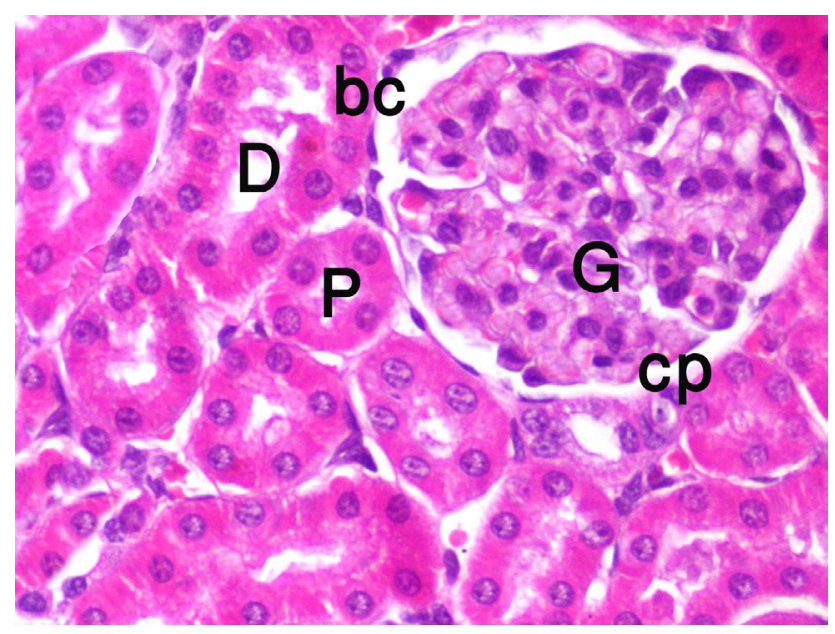

Fig. 4: A photomicrograph of G1(G2 showed the same results) kidney section showing typical glomeruli $(\mathrm{G})$, obvious capsular space (cp), a flat epithelium of the glomerular capsule (bc), glomerular capsular space (CP), thickened cubical epithelium of the proximal convoluted tubules (P) and a low simple cubic epithelium of the distal convoluted tubules (D). $(H \& E \mathrm{X} 400)$

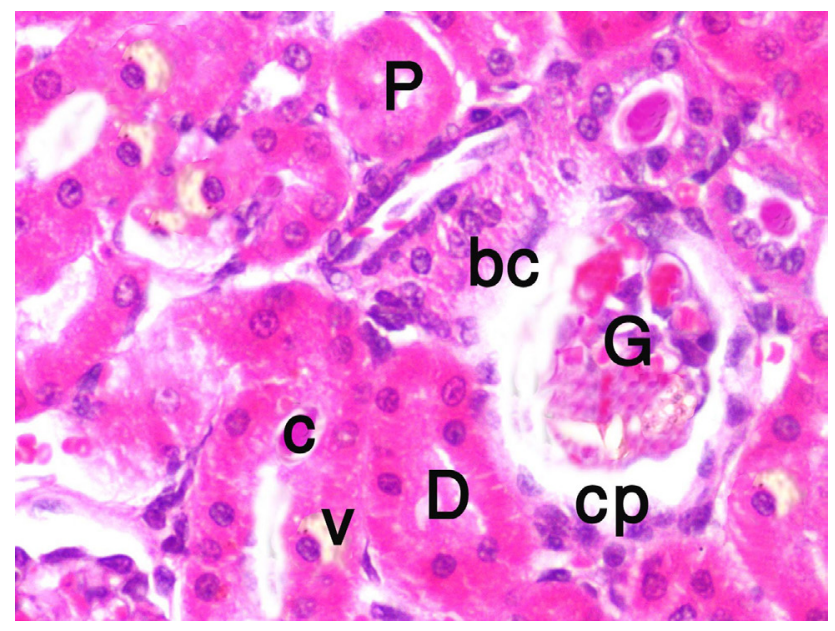

Fig. 5: A photomicrograph of G3 kidney section showing necrosis and glomerular atrophy $(\mathrm{G})$. great vacuoles $(v)$ in the epithelium of tubules, distinct glomerular capsular space (cp), destroyed flat epithelium that lines Bowman's capsule (bc), tubular cellular atrophy of proximal (P) and distal tubules (D), beside the presence of tubular casts (c).(H\&E X400)

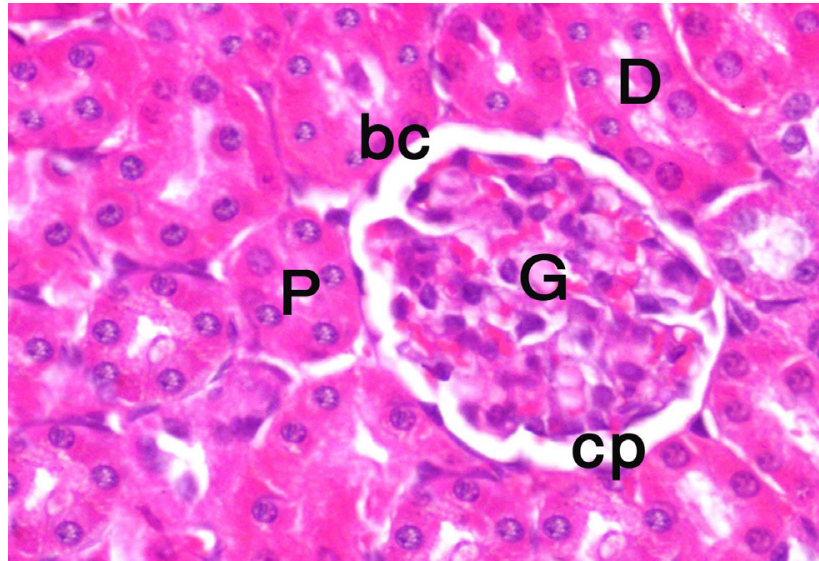

Fig. 6: a photomicrograph of section in G4 rat kidney revealing almost typical glomeruli $(\mathrm{G})$, a flat epithelium lining of the glomerular capsule (bc), obvious capsular space (cp), normal proximal (P) and distal (D) convoluted tubules. (H\&E X400)

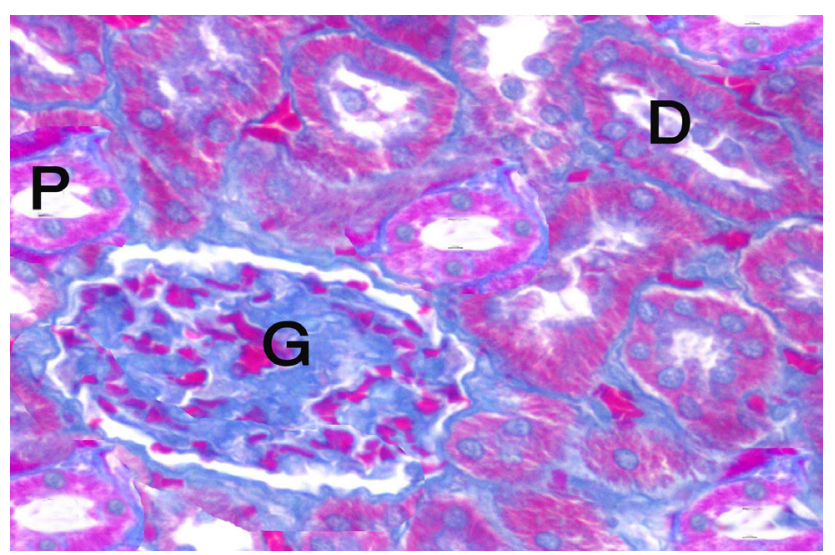

Fig. 7: A photomicrograph of G1(G2 showed the same results) kidney section showing typical normal histological appearance of glomeruli $(\mathrm{G})$ typical normal proximal (P) and distal (D) convoluted tubules, interstitial tissues contain few connective tissue.(Mallory X400)

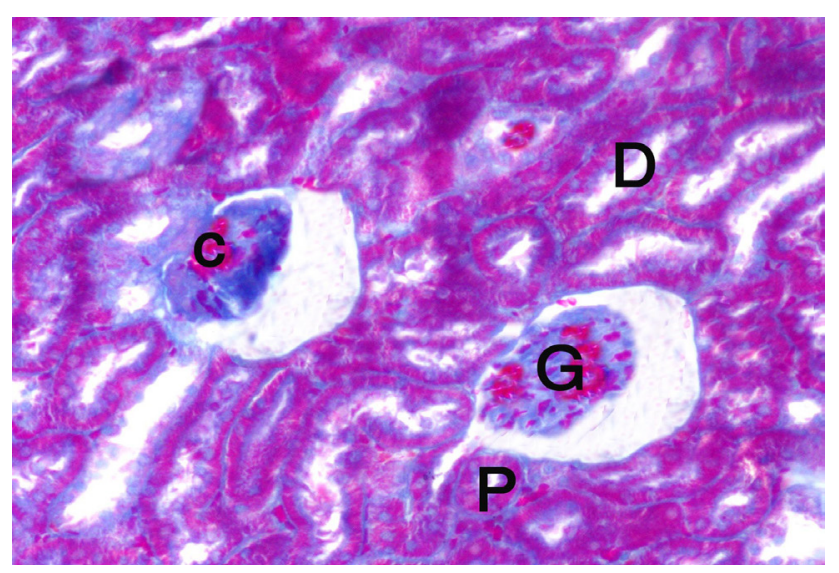

Fig. 8: A photomicrograph of G3 kidney section showing congestion (c) of vessels of glomeruli $(\mathrm{G})$ with several foci of interstitial fibrosis proximal (P) and distal (D) convoluted tubules. (Mallory X400) 


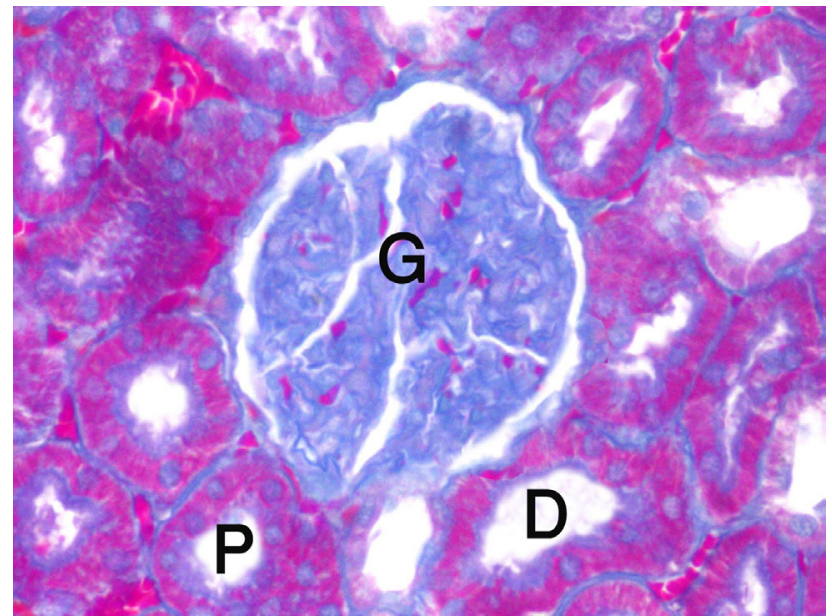

Fig. 9: A photomicrograph of G4 kidney section showing almost typical glomeruli (G), proximal (P) and distal (D) convoluted tubules. The interstitial tissues contain few connective tissue.(Mallory X400)

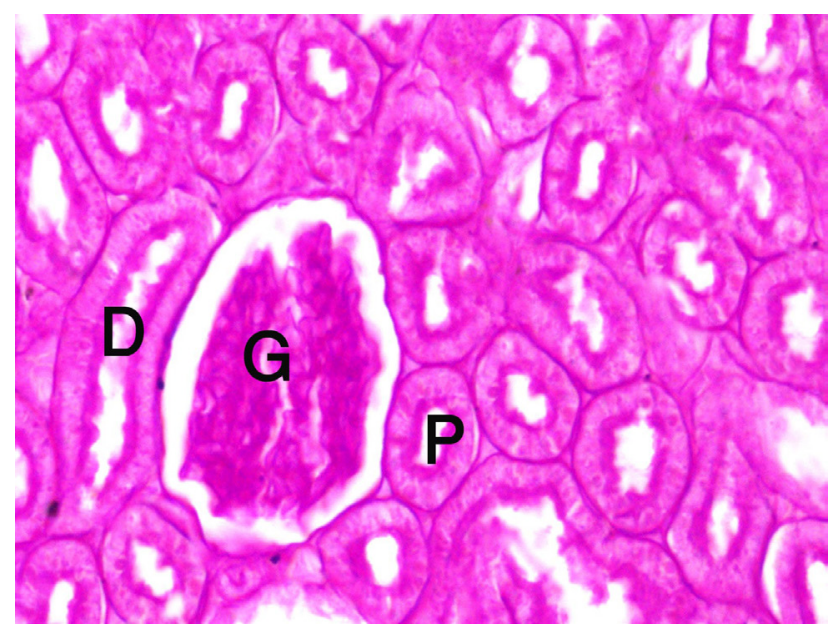

Fig. 10: A photomicrograph of G1(G2 showed the same results) kidney section showing strong positive reaction in the glomeruli $(G)$, brush border of the convoluted tubules :proximal (P)and distal (D) (PAS X400)

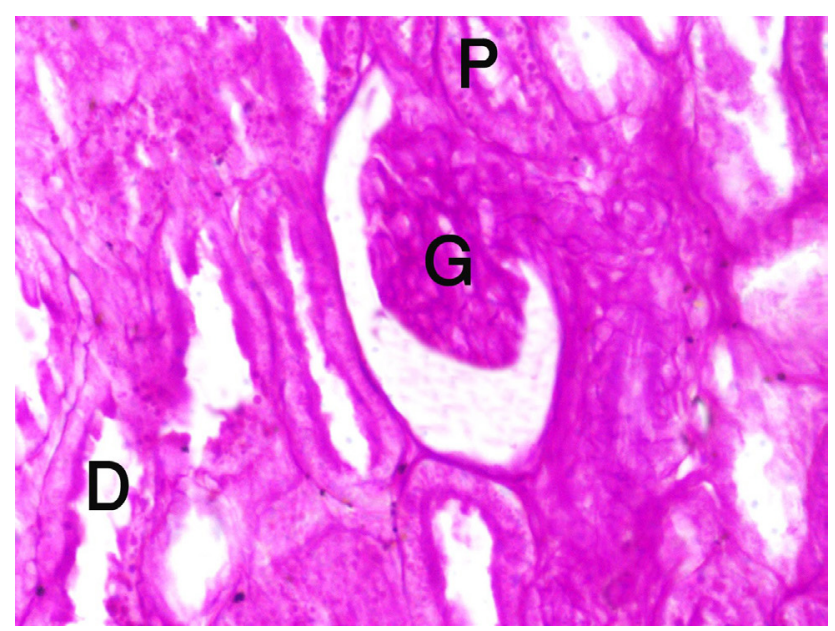

Fig. 11: A photomicrograph of G3 kidney section showed weak positive reaction in renal glomeruli $(\mathrm{G})$ and moderate reaction in the renal tubules: proximal (P) and distal (D) . (PAS X400)

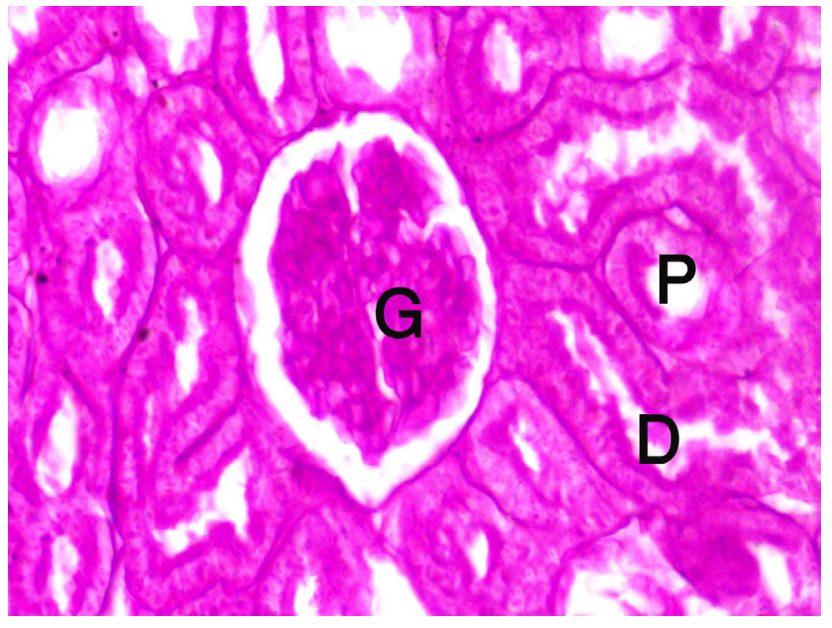

Fig. 12: A photomicrograph of G4 kidney section showing strong positive reaction in renal glomeruli $(\mathrm{G})$ and the brush border of tubules of kdney either proximal (P) or distal (D) .(PAS X400)

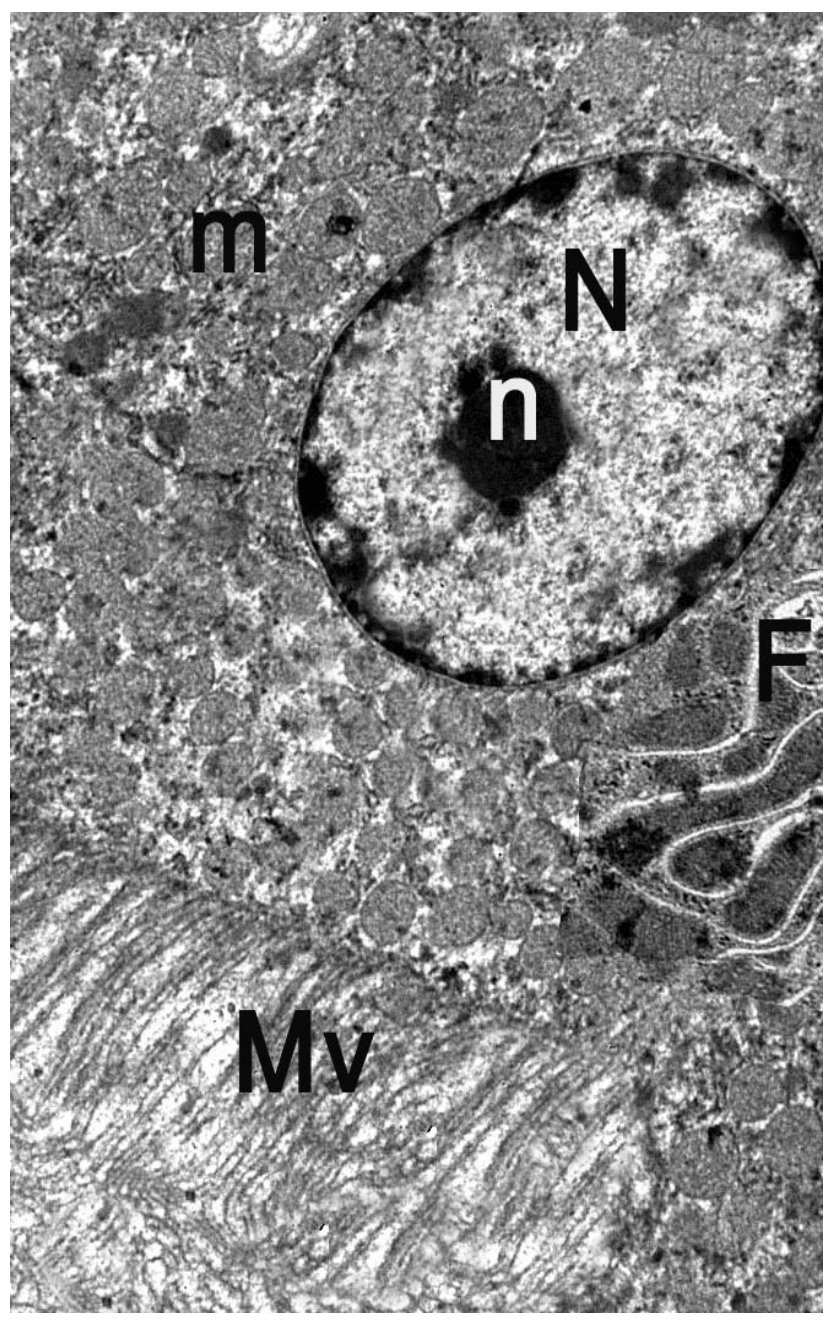

Fig. 13: An electron micrograph of a section in Proximal convoluted tubules of G1(G2 showed the same results) of rat kidney showing a great spherical nucleus $(\mathrm{N})$ with a little nucleolus (n), basal enfolding (F) with almost healthy microvilli (Mv) and many mitochondria (m).(X12000) 


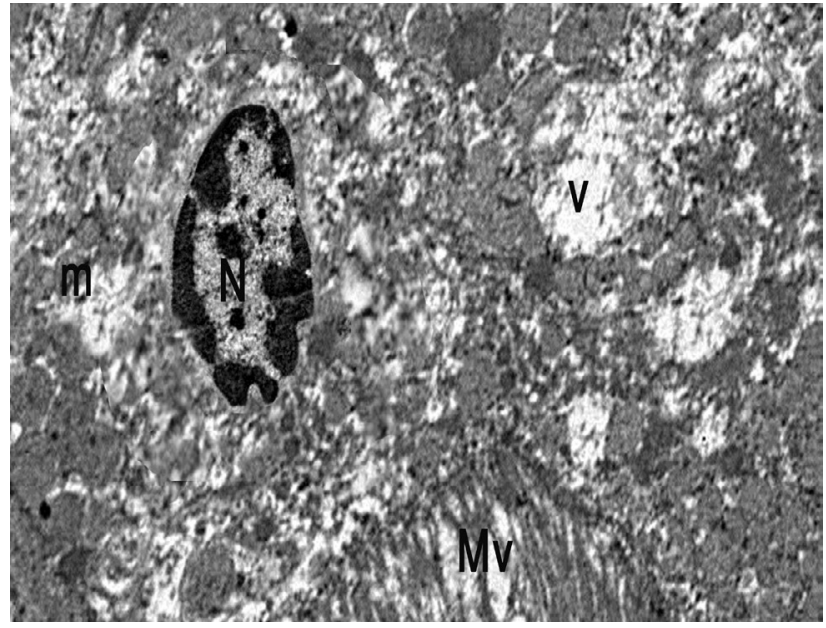

Fig. 14: An electron micrograph of a section in convoluted tubules of G3 of rat kidneyrevealing disturbance of many cytoplasmic organelles with the existence of vacuoles $(\mathrm{v})$, distended mitochondria $(\mathrm{m})$, disrupted microvilli (Mv) and shrunken small nucleus (N. (X12000)

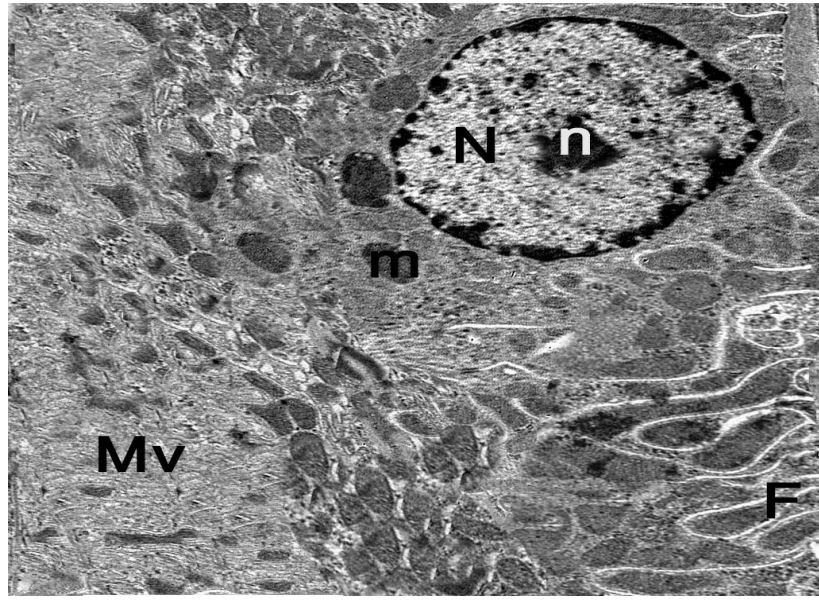

Fig. 15: An electron micrograph of a section in convoluted tubules of G4 of rat kidneyrevealing almost a typical nucleus $(\mathrm{N})$ with a tiny nucleolus (n), basal enfolding (F) with almost healthy microvilli (Mv) and many mitochondria $(\mathrm{m})$.(X12000)

Table 1: Showing urea and creatinine levels among various groups

\begin{tabular}{lcccc}
\hline & First Control & Second Arabic Gum & Third CsA & Fourth CsA+ Arabic gum \\
\hline Urea $(\mathrm{M} \pm \mathrm{SD})$ & $28.21 \pm 6.34$ & $27.4 \pm 4.02^{* *}$ & $81.2 \pm 6.06^{*}$ & $27.12 \pm 1.56^{* *}$ \\
Creatinine(M $\pm \mathrm{SD})$ & $0.91 \pm 0.11$ & $0.88 \pm 0.17^{* *}$ & $6.12 \pm 0.45^{*}$ & 356.406 \\
\hline
\end{tabular}

SD: Standard deviation

* $P<0.001$ refers to Significant result when compared with G1

** $P<0.001$ refers to Significant result when compared with G3

$F$ : The value of the difference between the groups.

Table 2: Showing the redox status parameters of four groups of rat

\begin{tabular}{|c|c|c|c|c|c|}
\hline & G1 & G2 & G3 & G4 & $\mathrm{F}$ \\
\hline $\mathrm{C}$ & $38.84 \pm 1.66$ & $37.58 \pm 2.31^{* *}$ & $11.01 \pm 1.98^{*}$ & $39.58 \pm 1.25^{* * *}$ & 555.513 \\
\hline$P$ & $15.51 \pm 1.22$ & $14.98 \pm 1.09^{* * *}$ & $6.09 \pm 1.05^{*}$ & $13.84 \pm 2.17^{\text {*** }}$ & 164.854 \\
\hline GSH & $93.32 \pm 1.51$ & $89.89 \pm 2.86^{* *}$ & $51.01 \pm 5.02^{*}$ & $92.52 \pm 1.08^{* *}$ & 447.757 \\
\hline MDA & $23.78 \pm 0.59$ & $25.12 \pm 1.95^{* *}$ & $61.3 \pm 1.77^{*}$ & $24.15 \pm 0.83^{* *}$ & 1.031 \\
\hline N.O & $48.66 \pm 4.35$ & $41.92 \pm 2.82^{* *}$ & $62.12 \pm 4.78^{*}$ & $46.92 \pm 2.22^{* *}$ & 68.208 \\
\hline S.D & $25.41 \pm 1.78$ & $25.98 \pm 1.21^{* * *}$ & $12.01 \pm 0.66^{*}$ & $25.12 \pm 1.65^{* * *}$ & 196.237 \\
\hline
\end{tabular}

C: Catalase

P:Peroxidase

GSH: Glutathione

MDA: Malondialdehyde

N.O: Nitric oxide

S.D: SuperoxideDismutase

* $P<0.001$ refers to significant result when compared with the $\mathrm{G}$

** $P<0.001$ refers to significant result when compared with the third group

F: The value of the difference between the groups. 


\section{DISCUSSION}

Cyclosporine-A has an immunosuppressive action but it is still the initial selected treatment in case of transplanted organ problems and rejection. The most complication of its prolonged use is a nephrotoxicity whereas modern studies had to get a way out for this renal damage by means of various substances which are naturally present. There is no enough experimental studies on the effect of Arabic Gum on the cellular state of renal tissues during the use of cyclosporine. The aim of this present work was to determine the use of Arabic gum to overcome the side effects of cyclosporine by improving the nephrotoxicity caused by it in trial to know the pathogenesis of the drug.

The present study reported that a statistical significant reduce was present in the rats' weights of both body and kidney of groupIII which was given cyclosporine-A when compared with group I and group II due to toxicity of cyclosporine, this happened due to anorexia and catabolic effect causing the loss of body weight, these results were in agreement with ${ }^{[15,19,20]}$ who revealed renal apoptosis as a reason of renal weight decrease.

A statestical significant increase of weight of both kidney and body in the rats of fourth group which given Arabic gum plus cyclosporine-A was present due to its antioxidant role which opposes effects of cyclosporine-A caused loss of the weight of both body and kidneys ,these results went in agreement with ${ }^{[9,10]}$ who detected that Arabic gum enhanced the weight of both body and kidneys in the rats which were given adenine-induced failure of kidneys

The present work concluded that cyclosporine-A caused significant raise of urea\& creatinine in the blood, these results were parallel with the results of ${ }^{15,21,22]}$. The present study showed renal cells apoptosis, these results were in agreement with ${ }^{[15,23]}$. According to ${ }^{[15,24]}$, renal pathological results and impairment due to cyclosporine intoxication produced oxidative stress which leads to reactive oxygen species (ROS) causing peroxidation of lipids in constant with $^{[15,25]}$ and our results revealed that raise in all of the oxidative parameters such as(malondialdehyde "MDA" and nitric oxide), and statestical significant reduce in (glutathione) and other enzymes like (catalase, superoxide dismutase and peroxidase) as a cause of elevated blood value of cyclosporine which produces oxidative stress for example enzyme inhibition and inactivation, disturbance of mitochondria beside cellular necrosis according to ${ }^{[26]}$. The present research showed that cyclosporine-A caused histopathological and ultrastructural deterioratins in the renal tissues of rats, these results were parallel to ${ }^{[15,21,22]}$.

This present work revealed that treatment by the use of both Arabic gum and cyclosporine together could cause improvement of the results of cyclosporine-A intoxication when compared with groupII that given cyclosporine only and this was parallel to the results of ${ }^{[14]}$ who showed that Arabic gum improved the toxic manifestations of indomethacin on renal tissues of rat. Moreover ${ }^{[27,28]}$. added that Arabic gum improved renal histopathological and ultrastructural pathological deteriorations of cisplatinevoked Nephrotoxicity in Rats.

\section{CONCLUSION}

Prolonged period of cyclosporine-A administration may result in oxidative stress and injury of renal tissues and deteriorations of renal function which were detected by histological and biochemical studies through the oxidative stress The utilize of Arabic gum accompanied with cyclosporine-A produced amelioration in renal damage manifestations due to its obvious antioxidant effect

\section{RECOMMENDATIONS}

The dual intake of Arabic gum as dietary natural substance during the period of extended intake of cyclosporine is suggested in patients with organ transplantation to adjust and improve the nephrotoxicity caused by it.

\section{ACKNOWLEDGEMENT}

The authors extend their appreciation to Taif university for supporting this work .Researchers supporting project under project number (TURSP-2020\116), Taif university, Taif, Saudia Arabia

\section{CONFLIC OF INTERESTS}

There are no conflicts of interest.

\section{REFERENCES}

1. Van Sandwijk MS, Bemelman FJ, Ten Berge IJ. Immunosuppressive drugs after solid organ transplantation. Neth J Med.2013; 71: (6):281-9.

2. Campistol JM, Sacks SH. Mechanisms of nephrotoxicity. Transplantation. 2000; 69: S5-10.

3. Sereno J, Rodrigues-Santos P, Vala H, Rocha-Pereira P, Alves R, Fernandes J, Santos-Silva A, Carvalho E, Teixeira F and Reis F. Transition from cyclosporineinduced renal dysfunction to nephrotoxicity in vivo rat model. Int J Mol Sci. 2014; 15(5):8979-97.

4. Reis F, Rocha-Pereira P, Teixeira de Lemos E, Parada B, Baptista S, Figueiredo A, Santos-Silva A, Costa-Almeida C, Mota A and Teixeira F. Oxidative stress in cyclosporine-induced hypertension: evidence of beneficial effects or tolerance development with nitrate therapy. Transplant Proc. 2007; 39(8):2494-500.

5. Sereno J, Vala H, Nunes S, Rocha-Pereira P, Carvalho E, Alves R, Teixeira F and Reis F.Cyclosporine A-induced nephrotoxicity is ameliorated by dose reduction and conversion to sirolimus in the rat. J Physiol Pharmacol . 2015; 66(2):285-99.

6. Nunes S, Madureira R, Campos D, Sarmento B, Gomes AM, Pintado $M$ and Reis F. Therapeutic and nutraceutical potential of rosmarinic acid - cytoprotective properties and pharmacokinetic profile. Crit Rev Food Sci Nutr. . 2015; 26:0. 
7. Amudha G, Josephine A and Varalakshmi P. Role of lipoic acid in reducing the oxidative stress induced by cyclosporine A. Clin. Chim. Acta 2006; 372(1-2):134-139.

8. Cologna A J, Lima LV, Tucci SJ, Suaid HJ et al.Cyclosporine action on kidneys of rats submitted to normothermic ischaemia and reperfusion. Acta Cirúrgica Brasileira. 2008; 23 (1): 36-41.

9. Badreldin H A, Al-Husseni I, Sumyia B , Al-Shukaili A, Abderrahim N, Simone S, Nina Q, Nicole S. Effect of Gum Arabic on Oxidative Stress and Inflammation in Adenine-Induced Chronic Renal Failure in Rats. PLOS ONE 2013; Volume 8 | Issue 2 1-7

10. Matsumoto N, Riley S, Fraser D, Al Assaf S, Ishimura E, Wolever T, Phillips GO, Phillips AO .Butyrate modulates TGF-betal generation and function: potential renal benefit for Acacia(sen) SUPERGUM (gum arabic)? Kidney Int. 2006; 69:257-265.

11. Mohammed A Z, Suhail A S, Yousuf A S, Priyadarsini M, Abderrahim N. Badreldin H A.Gum Acacia Improves Renal Function and Ameliorates Systemic Inflammation, Oxidative and Nitrosative Stress in Streptozotocin-Induced Diabetes in Rats with Adenine-Induced Chronic Kidney Disease. Cell Physiol Biochem. , 2018; 45:2293-2304

12. Tiss A, Carrière F, Verger R.Effects of gum arabic on lipase interfacial binding and activity. Anal Biochem. 2001; 294:36-43.

13. Nasir O, Umbach A T, Rexhep R, Ackermann T F, Madhuri B, Ebrahim A, Ferruh A ,Daniela S,Kempe a Goverdhan Puchchakayala a Balasaheb S, Michael F, Saeed A, Lang F.Effects of Gum Arabic (Acacia senegal) on Renal Function in Diabetic Mice. Kidney Blood Press Res. 2012; 35:365-372.

14. Elshama S S, El-Kenawy A E-M, Osman H-E H, Youseef HM. Amelioration of indomethacin systemic toxicity by gum arabic administration in adult albino rats. International Journal of Medicinal Plants and Alternative Medicine .2014 ; 2(3), pp. 032-046

15. Elshama S S, Osman H.-E. H and El-Kenawy A EM. Renoprotective Effects of Naringenin and Olive Oil against Cyclosporine- Induced Nephrotoxicity in Rats. Iranian Journal of Toxicology.2016; 10( 5): 27-37.

16. Li J, Dahmen U, Beckebaum S, Cicinnati V, ValentinGamazo C, Frilling A, Malago $M$ and Broelsch CE. Target range maximum of cyclosporine blood concentration two hours post dose in stable liver transplant patients, Eur J Med Res. 2006; 11: 139-145.

17. Bancroft JD and Gamble M. Theory and Practice Histological Techniques, $5^{\text {th }}$ ed., Churchill
Livingstone. New York, Edinburgh and London. 2002; pp 126 and 173-175.

18. Graham L , Orenstein JM. Pocessing tissue and cells for transmission electron microscopy in diagnostic pathology and research. Nat Protoc. 2007; 2(10):2439-50.

19. Davalos A, Gomez-Cordoves C , Bartolome B .Commercial dietary antioxidant supplements assayed for their antioxidant activity by different methodologies. J Agr Food Chem. 2003; 50: 5909-5914.

20. Wongmekiat O, Leelarugrayub $\mathrm{N}$, Thamprasert $\mathrm{K}$. Beneficial effect of shallot (Allium ascalonicum L.) extract on cyclosporine nephrotoxicity in rats. Food Chem Toxicol. 2008; 46:1844-50.

21. ChakravarthiS,FuWenCandHaleagraharaN.Apoptosis and expression of bcl-2 in cyclosporine induced renal damage and its reversal by beneficialeffects of 4', 5', 7'- trihydroxyflavone. Journal of Analytical BioScience. 2009; 32( 4): 320-327.

22. Slattery C, Campbell E, McMorrow T, Ryan MP Cyclosporine A-induced renal fibrosis: a role for epithelial-mesenchymal transition. Am J Pathol. 2005; 167(2):395-407.

23. Abdel aal K, Mubark HA, Abdel hady RH, Abdel moneim WM , Hussein AMR. Protective Effect of Aminoguanidine Against Cyclosporine Induced Nephrotoxicity and Hepatotoxicity in Rats: Histological and Biochemical Study. Med. J. Cairo Univ.2009; 77(1): 181-191.

24. Buffoli $\mathrm{B}$, Pechànovà $\mathrm{O}, \mathrm{Koj}$ sovà $\mathrm{S}$, Andriantsitohaiana R, Giugno L, Bianchi R , Rezzani R . Provinol prevents CsA-induced nephrotoxicity by reducing reactive oxygen species, iNOS, and NFkB expression. J. Histochem. Cytochem.2005; 53: 1459-1468.

25. Lee J. Use of Antioxidants to Prevent Cyclosporine A Toxicity. Toxicol. Res.2010;. 26( 3): 163-170.

26. Clement MV , Pervaiz S. Intracellular superoxide and hydrogen peroxide concentrations: a critical balance that determines survival or death. Redox Rep. 2001;6: 211-214.

27. Benzie IF. Evolution of dietary antioxidants. Comp. Biochem. Physiol. A Mol. Integr. Physiol. 2003;136: 113-126.

28. Abdulhakeem A. Al-Majed, Adel R. A. Abd-Allah, 1 Ammar. Al-ikabi, Othman A. Al-Shabanah, Adel M. Mostafa.Effect of Oral Administration of Arabic Gum on Cisplatin-Induced Nephrotoxicity in Rats. J Biochem Mol Toxicol . 2003;17(3):146-53. 
الملخص العربى

\title{
التأثيرات الكلوية للعلكة العربية ضد السيكلوسبورين - المسبب للسمية الكلوية في الفئران حسام الدين حسين عثمان'، دعاء جلال الصحر '، أيمن المغاوري القتاوي"، رشا سالم؛
}

\author{
اقتسم التشريح كلية الطب جامعة الطائف \\ بامعة التكنولوجيا و المعلومات الحديثة
}

"قمب علم الأمراض ـ كلية الطب - جامعة الطائف ـ قسم البيولوجيا الجزيئية ـ معهد الطب الثرعي - جامعة مدينة السادات

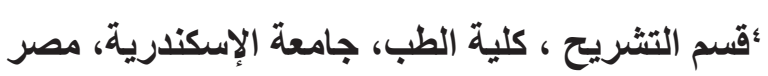

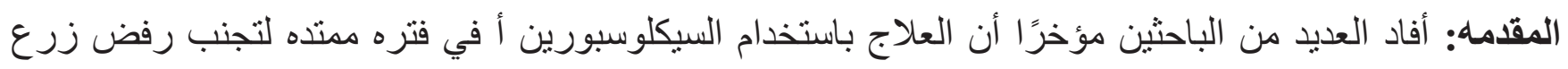

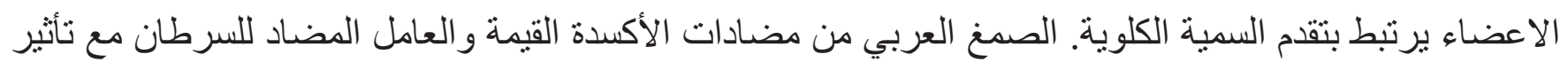
وقائي ضد التسمم الكلوي. الهدف: تهدف هذه الدراسة إلى تقييم الدور الوقائي للصمغ العربي في تحسين السمية الكلوية للسيكلوسبورين أ في

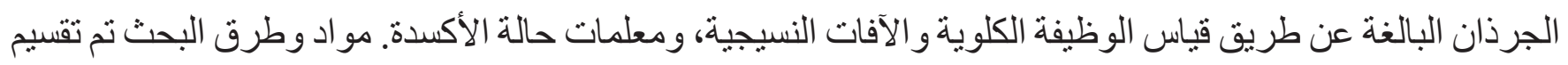

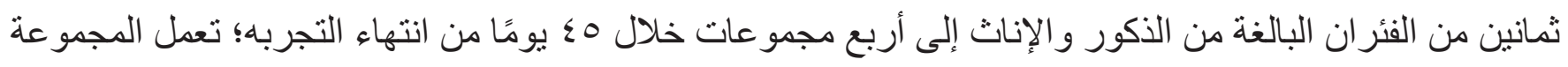

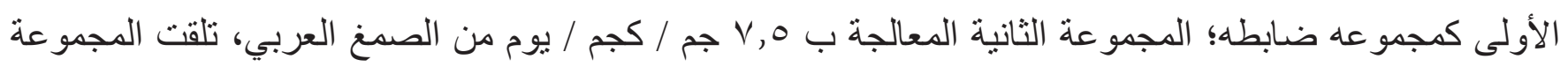

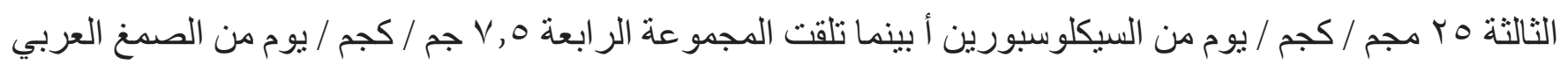

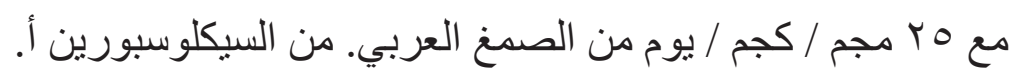
النتائج: كان لدى الفئران المعالجة بالسيكلوسبورين أ خلل وظيفي كلوي، كما تم الإبلاغ عنه من خلال علان علامات عالية في

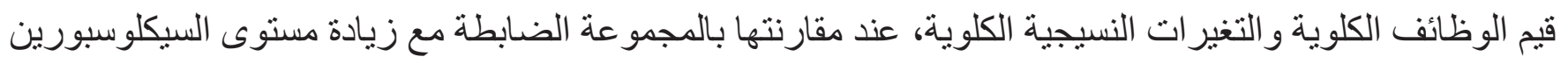

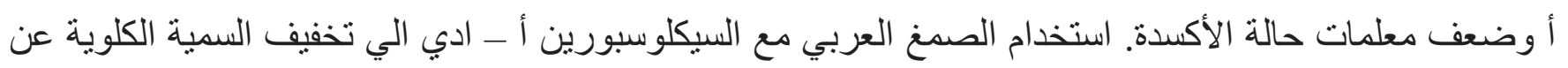

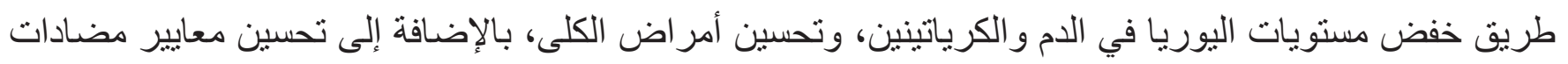

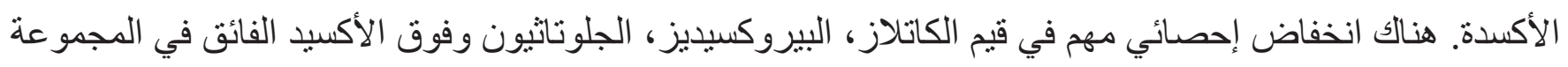

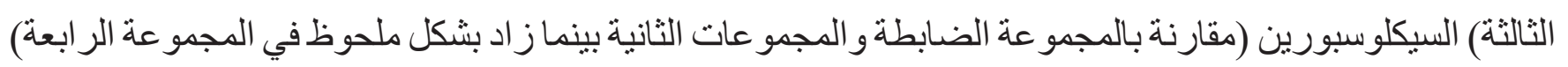

السيكلوسبورين و الصمغ العربي (بالمقارنة مع المجمو عة الثالثة) السيكلوسبورينة بالثين. الاستتتاج: من المحتمل أن يعمل الصمغ العربي كعامل طبيعي للوقاية من السكلوسبورين أ المسبب لسميه كلويه. 